\title{
Kebijakan Negara Tentang Privatisasi Dalam Pengelolaan Sumber Daya Air Dalam Relevansinya Dengan Keadilan Sosial Ekonomi
}

\author{
Rahmida
}

Dosen Fakultas Hukum Universitas Lambung Mangkurat

\section{Pendahuluan}

Momentum peringatan Hari Air sedunia yakni tanggal 22 Maret dan dicanangkannya tahun 2008 sebagai tahun Sanitasi Internasional, juga kesepakatan internasional menghasilkan Millenium Development Goals (MDGs) yang salah satu programnya mencanangkan tahun 2015 sebagai tahun implementasi kesepakatan tersebut. Hal ini membuat banyak pihak terutama pemerintah Indonesia segera bersiap-siap menghadapinya dengan terus memperhatikan hal-hal yang berkaitan dengan penyehatan lingkungan, penyediaan air bersih bagi masyarakat dan pengelolaan sanitasi yang baik. Sebagai salah satu Negara yang ikut menandatangi kesepakatan internasional tersebut, terutama berkenan dengan air bersih dan sanitasi, maka Indonesia seyogyanya segera berbenah untuk itu.

Sejumlah elemen eksekutif yang terlibat untuk menangani permasalahan itu adalah BAPENNAS, DepKes, DepDagri, Departemen PU, Departemen perindustrian dan Kementerian Lingkungan Hidup. Disamping itu dituntut pula dukungan dan peran serta seluruh pemerintah daerah di Negara ini.

Permasalahan berkenaan dengan air di Indonesia memang bukanlah hal yang kecil, karena permasalahan air menjadi hal yang amat penting untuk diselesaikan, selain memang air merupakan kebutuhan pokok bagi kelangsungan hidup manusia, kebutuhan akan air juga menjadi penting dalam kaitannya dengan peningkatan ekonomi masyarakat terutama bagi terlaksananya pertanian dan perkebunan rakyat juga sebagai pendukung penumbuhan dan kelangsungan industri-industri rakyat di Negara ini.

Dalam berbagai diskusi yang bersifat internasional terungkap berbagai masalah yang cukup berat yang dialami Indonesia di dalam pencapaian cita-cita mewujudkan kesepakat in MDGs. Dimana dalam kesepakatan MDGs itu ditargetkan tahun 2015 cakupar pelayanan air minum dan sanitasi yang baik dalam suatu Negara tercapai minimal 79 $\%$. Tetapi Indonesia menurut beberapa sumber laporan menyebutkan bahwa mengalami kemunduran dalam pencapaian target MDGs tersebut. Cakupan pelayanan air bersih bagi masyarakat hanya mencapai $40 \%$ di perkotaan dan $8 \%$ di pedesaan. ${ }^{1}$ Padahal berdasarkan proyeksi BPS (Badan Pusat Statistik) pada tahun 2015 nanti terjadi pertumbuhan penduduk yang mencapai jumlah 247,5 juta jiwa dan proyeksi kebutuhan akan air bersih mencapai 9,391 miliar kubik perkapita pertahun. Bagaimana keadaan ini sanggup untuk diselesaikan pemerintah Indonesia sedangkan

\footnotetext{
${ }^{1}$ Laporan Khusus Majalah Air Minum "Menyiasati Kelangkaan Air Semoga Tidak Hanya Sekedar Wacana", Majalah Bulanan Air Minum Edisi April 2007, Hlm. 16
} 
selama ini pelayanan air bersih bagi masyarakat masih dianggap dalam jumlah yang kecil. Salah satu penyebab hal tersebut disinyalir karena terkait pula dengan semakin langkanya air baku yang baik untuk diolah menjadi air bersih/air minum.

Meskipun Indonesia sebagai salah satu dari sepuluh (10) Negara yang kaya akan sumber daya air, namun ternyata krisis air baku tetap saja menjadi persoalan di negeri ini. Neraca air di Pulau Jawa tahun 2000 memperlihatkan bahwa ketersediaan air hanya sekitar 1750 meter kubik perkapita pertahun, jauh di bawah standart kucukupan yang sekitar 2000 meter kubik perkapita pertahun. Jumlah tersebut diperkirakan akan terus menurun jika tidak diperhatikan penanggulangannya. ${ }^{2}$ Selain di pulau jawa maka disinyalir daerah yang mengalami kelangkaan sumber air baku adalah daerah Bali dan Nusa Tenggara serta Sulawesi Selatan.

Kondisi ini juga semakin diperparah dengan adanya pencemaran air baku yang ida disungai-sungai dan air tanah yang tercemar oleh berbagai sebab, terutama oleh air limbah rumah tangga. Dan data yang ada di catatan Kelompok kerja Air Minum dari Bappennas, bahwa 76,2 \% dari 52 sungai di Jawa, Sumatera, Bali dan Sulawesi tercemar berat oleh pencemaran organik dan 11 sungai utama tercemar pula oleh ammonium.

Penanganan mengenai air bersih yang kurang dan pengelolaan akan sanitasi masyarakat yang buruk serta kurangnya kepedulian pemerintah akan kedua hal ini, maka seringkali masalah kurangnya

${ }^{2}$ Ibid, Hlm. 17 tersedia air bersih dan sanitasi yang buruk membuat kesejahteraan kehidupan masyarakat juga buruk di lihat dari segi kesehatannya. Dari data Departemen Kesehatan RI bahwa tahun 2002 telah terjadi 5 789 kejadian luar biasa akibat Dari yang menyebabkan kematian sebanyak 94 orang.

Meskipun dengan adanya UU Nomor 7 Tahun 2004 tentang Sumber Daya Air mengharuskan adanya keterpaduan antara air minum dan air limbah, artinya perlunya penanganan penyediaan air bersih dengan juga pengelolaan yang baik terhadap air limbah agar bermanfaat dan tidak mencemari sumber-sumber air baku. Namun ternyata penanganan air limbah di beberapa daerah di nagara ini belum dikelola dengan baik bahkan cenderung terabaikan. Selama ini pembangunan di bidang air cenderung berorientasi pada pengelolaan air baku menjadi air minum atau air bersih, tetapi tidak memperhatikan buangan yang dihasilkan dari penggunaan air bersih tersebut. Hasil buangan dari penggunaan air bersih tersebut seringkali menjadi air limbah yang terabaikan tanpa penanganan yang baik dan tanpa pemikiran pemanfaatannya kembali. Padahal seringkali air limbah hasil buangan dari penggunaan air bersih itu berdampak buruk pada air baku dengan kata lain seringkali menceraari air baku. Belum lagi menurut catatan harian Kompas, bahwa 3,5 \% jamban di Indonesia ini tidak dilengkapi sarana air bersih, dan pembuangannya mengalir ke sungai, atau mencemari sungai, padahal sungai-sungai tersebut merupakan sumber air baku yang akan diolah menjadi air bersih. 
Selain itu salah satu pencemar terhebat terhadap air baku adalah air limbah hasil buangan rumah tangga, yakiii air yang mengandung deterjen. Banyak di Indonesia ini produk deterjen yang sangat aktif dan sangat kuat sehingga sangat besar pengaruhnya mencemari air sungai yang merupakan sumber air baku bagi pengolahan ah bersih. Padahal kalau kita mau berkaca ke luar negeri, misalnya di Negara negara Erofa sudah ada kebijakan negaranya untuk ketentuan produksi deterjen yang tidak boleh melebihi standart yang telah ditentukan yang iman bagi manusia dan lingkungan hidup.

Memang
khususnya pemerintah $r$ daerah -
pemerintah daerah di beberapa
wilayah di negeri ini berupaya
menangani persoalan air bersih dan
sanitasi lingkungan masyarakatnya,
namun terkadang r tidak
merlaksnakan program secara
maskimal karena cenderung
kebijakan yang dibuat bersifat
parsial dan sesaat tidak
berkesinambungan, sehingga seolah tambal sulam akibatnya hasil yang didapat juga tidak maksimal.

Belum terselesaikannya berbagai persoalan berkaitan dengan air bersih, tetapi sekarang ini pemerintah Indonesia sebagai salah satu yang ikut dalam kesepakatan internasional yakni kesepakatan berkenaau dengan air bersih dan lingkungan bersih (sanitasi baik) dalam kesepakatan MDGs, maka sebagai salah upaya mewujudkan apa yang dituangkan dalam kesekatan internasional itu pemerintah Indonesia mencanangkan bahwa mulai tahun 2008 perusahaan - perusahaan air minum di Indonesia sudah memproduksi tidak hanya air bersih tetapi naik klasifikasinya menjadi air minum. Dan kebijakan ini sejalan dengan harapan yang tersirat dalam Peraturan Pemerintah Nomor 16 tahun 2005 sebagai pelaksana dari UU Nomor 7 Tahun 2004 tentang Sumber Daya Air.

Sudah sejak lama memang isu itu mengemuka, tetapi realitasnya jauh dari harapan. Banyak berbagai kendala yang dihadapi perusahaanperusahaan air minum (PAM) di negeri ini semisal mengenai persoalan umumnya menyangkut pendanaan yang dirasa masih kurang untuk mewujudkan harapan tersebut, juga persoalan management perusahaan dan juga persoalan teknologi yang masih kurang dikuasai SDMnya. Walaupun sedikit-demi sedikit persoalan itu dicoba diselesaikan, namun sanggupkan perusahaanperusahaan air minum (PAM) di negeri ini menjalankan kebijakan tersebut, belum lagi persoalan yang selama ini belum terselesaikan di antaranya kurangnya atau langkanya air baku dan pencemaran terhadap air baku.

Kebijakan pemerintah yang berkenaan dengan peningkatan air bersih menjadi air minum yang tertuang dalam kebijakan berbentuk PP (Peraturan Pemerintah) Nomor 16 Tahun 2005 ini memang sebagai suatu kebijakan yang dibuat ini mendorong pemerintah untuk membuat kebijakan yang sejalan dengan maksud dan tujuan yang tertuang dalam kesepakatan Mellinium Development Goals (MDGs). Di mana keharusan suatu Negara mencapai pelayanan publik tentang penyediaan air bersih bagi masyarakat minimal $79 \%$.

Disaamping kebijakan tersebut 
yang tertuang dalam PP No 16 Tahun 2005, kebijakan Negara yang berkenaan dengan pengelolaan sumber daya air juga dapat kita cermati yakni tentang adanya peluang bagi non pemerintah yakni swasta baik perorangan maupun kelompok (perusahaan) untuk masuk dalam hal pengelolaan sumber daya air (SD Air) baik air tanah maupun air pemukaan. Hal ini menunjukkan adanya system privatisasi dalam pengelolaan SD Air.

Indonesia sebenarnya telah pernah mengalami suatu keadaan atau pengalaman yang buruk dalam hal privatisasi sumber daya alam apalagi yang merupakan cabang produksi yang penting bagi Negara yang menyangkut hajat hidup orang banyak, ambil contoh privatisasi dalam pertambangan emas, batubara, privatisasi lainnya seperti pada beberapa BUMN di bidang usaha kelistrikan dan telekomunikasi.Kadang dalam pelaksanaan proses pembangunan dan pengelolaan dalam kaitannya dengan privatisasi ini kurang baik dalam artian kurang sejalan tujuan untuk membangun kondisi pasar yang stabil, karena kadangkala terjadi kemandulaan pelaksanaan regulasi ekonomi yang kerapkali juga berdampak buruk pada kesejahteraan masyarakat. Privatisasi dalam SD Air ambil contoh PAM Jaya di Jakarta, suatu fenomena yang nyata yang dapat kita cermati bagaimana selanjutnya PAM Jaya dalam era privatisasinya. Dalam kebijakan yang ada ternyata PAM Jaya berada dalam kesepakatan privatisasi dalam kurun waktu yang lama yakni 25 hingga 30 tahun, dan kepemilikan saham swasta asing ternyata telah mencapai angka 95\% dan swasta nasional $5 \%$. $^{3}$

\section{Kebijakan Negara Mengatasi krisis Air Bersih}

Beberapa waktu yang lalu 189 negara di dunia yang terdiri dari Negara negara maju dan NegaraNegara berkembang dan Negara miskin, kesemua Negara menyepakati suatu bentuk kerjasama internasional yakni Model Pembangunan Mellinium yang dikenal dengan istilah MDGs, dalam kesepakatan internasional ini maka masing-masing Negara harus selalu memperhatikan pembangunan di negaranya yang harus mencerminkan semangat MDGs. Program internasional tersebut bertujuan sebagai bentuk penyelamatan bangsa-bangsa terhadap berbagai ketimbangan yang kini menjadi potret umum di hampir disetiap belahan dunia. Potret social itu berupa kemiskinan, tingginya angka kematian ibu dan bayi, rendahnya tingkat pendidikan warganegara, ketidaksetaraan gender dan persoalan pencemaran lingkungan serta krisis air bersih.

Indonesia sebagai salah satu Negara peserta yang ikut dalam pertemuan internasional yang digagas oleh PPB tersebut, dan telah pula menandatangani perjanjian atau kesepaktan internasional itu maka sebagai kounsekuensinya maka Negara Indonesia dalam setiap program pembangunannya harus selalu mengupayakan tercapainya tujuan dari MDGs itu. Apabila gagal akan berdampak kepada citra bangsa Indonesia di mata dunia

\footnotetext{
${ }^{3}$ Suteki, Rekontruksi Politik Hukum Hak Atas Air Pro Rakyat, Malang, Surya Pena Gemilang,2010,hlm.9
} 
internasional. Oleh karena itu wajar kalau pemerintah Indonesia selalu mencoba menyusun setiap program pembangunannya dengan penuh perhatian untuk segala hal termasuk yang berkaitan dengan tujuan MDGs itu.

Demikian pula dengan pembangunan yang berkaitan dengan air atau sumber daya air. Karena salah satu dari sekian target dalam MDGs adalah meningkatkan akses masyarakat miskin terhadap air bersih. Dalam hal ini ditargetkan tahun 2015 tercapai peningkatan jumlah masyarakat miskin yang dapat mengakses air bersih, yakni harus mengurangi separuh dari jumlah masyarakat miskin selama ini yang belurn dapat mengakses air bersih. Dalam hal ini Pemerintah mencoba menyusun kebijakankebijakan yang berkaitan dengan sumber daya air. Diantaranya adalah UU Nomor 7 Tahun 2004 tentang Sumber Daya Air, Undang-undang ini dibentuk sebagai suatu kebijakan Negara yang merupakan kounsekuensi dari keikutsertaan Negara Indonesia dalam menandatangani MDGs.

Sebagai peraturan pelaksana dari UU Nomor 7 Tahun 2004, maka pemerintah Indonesia selanjutnya membuat kebijakan lanjutan berupa Peraturan Pelaksana dari LU tersebut. Yakni Peraturan Pemerintah Nomor 16 Tahun 2005 tentang Pengembangan Sistem Penyedian Air Minum. Dirnana dalam Peraturan Pemerintah ini ditegaskan bahwa adanya kesediaan air bersih untuk masyarakat, bahkan perlu ditingkatkan menjadi air minum, artinya air yang dapat langsung diminum.

Terkait hal tersebut di atas pemerintah melalui Departemen
Pekerjaan Umum telah mencanangkan agar mulai tahun 2008 ini produk perusahaan air minum (PDAM) yang ada di Indonesia ini tidak hanya memproduksi air bersih tetapi meningkatkan menjadi air minum. Yang mana hal tersebut juga telah diamanatkan dalam PP Nomor 16 tahun 2005. Tetapi banyak pihak masih meragukan kemampuan beberapa perusahaan iar dalam hal ini, karena menurut beberapa pihak peiaksanaan dari apa yang tersirat dalam kebijakan pemerintah itu (PP 16 / 2005) itu dan kebijakan Depertemen Pekerjaan Umum tentang menaikan produksi perusahaan-perusahaan air dari memproduksi air bersih menjadi air minum, bukanlah suatu hal yang mudah tidak semudah membalikkan telapak tangan. Seperti yang dikemukakan ketua Badan Pendukung pengembangan Sistem Penyediaan Air Minum (BPPSPAM) Ir Rachmat Karnadi, M.T bahwa semua pihak harus bijaksana menyikapi kebijakan pemerintah mengenai hal itu. Yang penting dari sejumlah PDAM yang ada di Indonesia ini diharapkan berusaha memulai kinerjanya agar sejak tahun 2008 ini memulai usaha menghasilkan produksinya tidak. hanya air bersih tetapi meningkat menjadi air minum. Setidaktidaknya mengupayakan agar PDAM menyediakan Zona pelayanan air minum, dan ZAMP. ${ }^{4}$ Berbagai kebijakan pemerintah yang berkaitan dengan air sudah dirumuskan dan telah diberi bentuk hukum sebagai sebuah

\footnotetext{
${ }^{4}$ Laporan Utama "Air Bersih Harus Naik Kelas jadi Air Minum”, Majalah Bulanan Air Minum, Edisi 131 Bulan Agustus Tahun 2006, Hlm. 6
} 
peruran hukum berupa Undang undang yakni UU Nomor 7 Tahun 2004 tentang Sumber Daya Air, yang kemudian dirumuskan pula kebijakan selanjutnya mengenai hal ini dalam bentuk Peraturan Pemerintah Nomomr 6 Tahun 2005, disamping beberapa kebijakan lainnya yang berkenaan dengan air.

Namun jika kita telaah lebih jauh mengenai kebijakan Negara berkenaan dengan air, maka dengan latar belakang keadaan dewasa ini di mana seringkali terjadi krisis air bersih. Tidak hanya di kota-kota besar yang padat pendudukanya di pedesaan juga yang tidak sedikit masyarakat yang hidup dalam garis kemiskinan dengan keterbatasan akan akses terhadap air bersih. Secara global juga di dunia ini sedang menghadapi masa-masa krisis yang mengarahkan pada krisis air bersih yang hebat pada 10 atau 20 tahun mendatang, itulah sebabnya maka PBB ( Perserikatan Bangsa-Bangsa ) melakukan gerakan dan langkah-langkah konkret mengatasi persoalan itu, tak terkecuali Indonesia. Berkenaan dengan hal itu maka patut kita telah lebih jauh bagaimana kebijakan Negara Indonesia menangani persoalan krisis air bersih ini.

Salah satu kebijakan Negara kita berkenaan dengan hal ini adalah dengan ikutsertanya Negara kita menandatangani kesepakatan MDGs yang salah satu dari sekian butir isi kesekapakatnya ialah mentargetkan agar meningkatkan akses masyarakat miskin terhadap air bersih. Disamping mencegah pencemaran dan pengrusakan lingkungan, meningkatkan kesetaraan gender, mengurangi tingkat kematian ibu dan anak, dan lain-lain.
Namun tidak hanya sekedar ikut menandatangani kesepakatan internasional itu saja, tetapi pemerintah seharusnya lebih meningkatkan langkah - langkah konkret dan serius dalam bentuk intervensi program dan pembiayaan langsung dari surnber anggaran publik dan penguatan peran sektor publik. Sekarang ini nampaknya pemerintah Indonesia kurang mengembangkan keikutsertaannnya membangun infrastruktur penyediaan dan pengolahan air bersih, ternyata kebijakan yang diambil pemerintah dalam hal ini justru sebaliknya dengan membuat kebijakan yang berupaya menitikberatkan pada mekanisme kerjasama pemerintah dan swasta (Public private patrnership) untuk membiayai penyediaan dan pengolahan air bersih dengan alasan bahwa keterbatasan anggaran pemerintah dalam hal ini. Disisi lain pemerintah justru mendorong komersialisasi air bersih dengan kebijakan memberikan izin seluasluasnya untuk penguasaan sumber daya air oleh perusahaan swasta (domestik dan asing). Sehingga nampaknya kebijakan pemerintah dalam hal swastanisasi atau privitasasi usaha - usaha yang bergerak dalam bidang sumber daya air scolah bertentangan dengan ketentuan dalam kebijalan hukumnya sendiri yakni dalam UU Nomor 7 tahun 2004 dan PP Nomor 16 Tahun 2005 yang notabenenya menggariskan bahwa pemenuhan sarana air bersih bagi setiap warga negara merupakan kewajiban bagi pemerintah pusat dan pemerintah daerah. Dalam garis kebijakan ini pemerintah seyogyanya yang paling bertanggungjawab akan tersedianya air bersih bagi warga negaranya. 
Oleh karenanya sepantasnya pemerintah pusat dan atau pemerintah daerah yang lebih serius dalam mengalokasikan anggarannya untuk pembangunan infrastruktur dalam hal penggeloalaan dan penyediaan air bersih, bukan malah menswastanisasikannya.

Kebijakan negara dalam hal penyediaan air bersih untuk mengurasi atau menghadapi krisis air bersih selama ini, adalah suatu kebijakan publik karena dalam hal ini sangat berkaitan dengan kepentingan publik atau orang banyak, bila kita lihat dalam pengertian suatu kebijakan publik maka dapat kita lihat dulu beberapa pengertian kebijakan negara atau kebijakan publik itu. Thomas R..Dye mendefinisikan kebijakan negara itu adalah " is whatever governments choose to do or not to do " (apapun yang dipilih oleh pemerintah untuk dilakukan atau tidak dilakukan) selanjutnya menurutnya bahwa jika pemerintah memilih untuk berbuat sesuatu maka haruslah ada tujuan (obyektif) dan seharusnya semua kebijakan negara itu meliputi semua tindakan pemerintah dan bukan hanya semata-mata keinginan belaka dari pemerintah atau pejabat pemerintah. $^{5}$ Dalam hal kebijakan negara mengenai sumber daya air dalam kaitannya untiik memenuhi kebutuhan masyarakat akan air bersih, dimana dalam situasi atau keadaan sekarang ini yang sedang menghadapi kelangkaan air, terutama kelangkaan air baku untuk diolah menjadi air bersih. Dalam hal ini pemerintah mengeluarkan berbagai kebijakan berkenaan

5 Thomas R.Dye, Understanding Public Policy, Englewood Clifts, N.J,7832, Prentice Hall, Inc.,3rded,1978,Hlm.3 dengan air sudah memenuhi suatu kreteria suatu Kebijakan Publik, karena kalau mengacu pendapatnya Thomas R. Dye tersebut di atas maka kebijakan yang dikeluarkan pemerintah dalam hal ini memiliki suatu tujuan untuk masyarakat luas (publik) dan mengatur kepentingan yang bersifat publik pula (Publik Interest). Pemerintah sudah berupaya sedemikian untuk melayani kepentingan publik. Dalam hal ini ada beberapa lembaga publik (Public institutions) yang saling bekerjasama. Dan dalam hal ini pemerintah dan jajaran sebagai pelayan publik dinamakan public bureaucracy. ${ }^{6}$

Dalam kaitannya dengan kebutuhan masyarakat akan air bersih, pemerintah sudah membuat berbagai kebijakan yang sifatnya sebagai sebuah kebijakan publik, karena tujuannya untuk kepentingan masyarakat atau kepentingan umum. Dalam perumusan suatu kebijakan publik yaug bertujuan untuk menyelesaikan suatu persoalan publik. Persoalan publik dapat diketahui dan adanya isu publik yang kemudian diusung oleh berbagai pihak untuk dapat menjadi suatu agenda penting bagi sebuah pemerintahan. Yang kemudian dari agenda pemerintah itu akan dirumuskan suatu kebijakan publik yang pada akhiraya dicari bentuk yang tepat untuk kebijakan tersebut dilihat dari materi dan ruang lingkup berlakunya kebijakan tersebut. Pada tahap selanjutnya dilakukan pengesahan dari sebuah kebijakan itu.

Pada tahap sebelum merumuskan kebijakan Publik maka harus bener-benar diketahui apa

\footnotetext{
${ }^{6}$ M.Solly Lubis,. 2007, Kebijakan Publik, Bandung: CV. Maandar Maju, Him. 1
} 
yang menjadi masalah, dan masalah yang ada dalam kehidupan masyarakat harus pula dapat dibedakan antara masalah sosial dengan masalah publik yang akan menjadi persoalan atau masalah kebijakan. Menurut William N. Dunn bahwa masalah kebijakan ( policy problem ) adalah nilai, kebutuhan atau kesempatan yang belum terpenuhi, yang dapat di identifikasikan, yang kemudian diperbaiki atau dipenuhi melalui tindakan publik. ${ }^{7}$ Berkaitan dengan kebijakan pemerintah atau kebijakan negara dalam hal air bersih ini, problem publik atau permasalahan publik dalam hal ini adalah krisis air bersih, yakni langkanya (kurangnya tersedia) air baku untuk diolah menjadi air bersih, dan permasalahan publik lainnya ialah rendahnya akses masyarakat terhadap air bersih. Di sini artinya ada kebutuhan masyarakat yang belum terpenuhi, baik mengenai akses terhadap air bersih ataupun terhadap keperluan dalam pengeolahan air bersih yang ternyata mengalami problem tentang keadaan sekarang dimana kurang tersedianya air baku. Untuk kondisi permasalahan publik seperti ini maka diperlukan kebijakan yang dapat mengatasinya. Salah satunya adalah kebijakan untuk segera menanggulangi kelangkaan air baku, selain itu juga menyusun kebijakan yang bertujuan agar dapat meningkatkan akses masyarakat terhadap air bersih terutama bagi masyarakat miskin diperkoataan atau di dipedesaan.

Langkah perumusan masalah

\footnotetext{
${ }^{7}$ William N.Dunn : 2003, Pengantar Analisis Kebijakan Publik, Yogyakarta, Gajahmada University. Hlm. 107
}

dapat memasok pengetahuan yang relevan dengan kebijakan yang mempersoalkan asumsi-asumsi yang mendasari definisi masalah dan memasuki proses pembuatan kebijakan melalui penyusunan agenda (agenda setting) Perumusan maslah dapat membantu menemukan asumsi-asumsi yang tersembunyi, mendiognosis penyebab-penyebannya, memetakan tujuan-tujuan yang memungkinkan memadukan pandangan-pandangan yang bertentangan, dan merancang peluang-peluang kebijakan yang baru. $^{8}$

Adapun proses pembuatan kebijakan (Policy making Process) meliputi proses politik yang berlangsung dalam tahap-tahap pembuatan kebijakan politik yang saling bergantung yang meliputi: penyusunan agenda kebijakan, formulasi kebijakan, adopsi kebijakan, implementasi kebijakan, dan penilaian kebijakan. Menurut Willian N Dunn bahwa proses seperti itu adalah suatu proses yang dapat dilukiskan sebagai siklus aktivitas yang berurutan rnenurut waktu dan bersifat tidak linear. ${ }^{9}$

Proses pembuatan kebijakan ini akan melibatkan berbagai elemen, baik dilibat dari pihak sebagai pengusung issu publik yang dapat berupa aktor resmi maupun aktor tidak resmi, juga dilihat dari siapa perumus kebijakan tersebut dan pihak mana pula sebagai pihak yang berwenang mengesahkan kebijakan itu.

Menurut Michael Howlett and M. Ramesh dalam bukunya Studying Public Policy, bahwa " Actors in the policy process may be either

\footnotetext{
${ }^{8}$ Ibid, Hlm. 26

${ }^{9}$ Ibid, Hlm. 45
} 
individuals or groups. As mentioned earlier, the actors involved in particular policy area can be referred to collectively as a policy subsystem. There is, however, almost an infinite variety of actors who may be members of policy subsystem and participative in the policy process., ${ }^{10}$ Jadi dalam proses pembentukan kebijakan publik akan melibatkan aktor yang menjadi pengusung issu publik agar ditanggapi oleh perumus kebijakan yang kemudian diagendakan sebagai suatu agenda penting untuk dibuatnya suatu kebijakan guna mengatasi persoalan publik atau masalah publik. Aktor itu dapat berupa aktor resmi yakni aktor yang terlibat dalam system yang berwenang merumuskan kebijakan publik itu, atau yang berada di luar system tersebut yang disebut aktor tidak resmi. Kalau kita kaitkan dengan kebijakan negara berkenaan dengan masalah air bersih ini maka dapat kita lihat dalam permasalahan krisis air bersih di negara ini, nampaknya terdapat aktor pengusung permasalahan ini yang tidak resmi yakni para aktivisaktivis lingkungan dan aktivis pembela rakyat miskin yang selalu berusaha memperjuangkan akses masyarakat akan ketersedian air bersih, dan para tokoh politik dari berbagai kekuatan partai. Adapun aktor resmi adalah para eksekutif yang berada di beberapa departemen, yakni Depertemen Pekerjaan Umum, Depertemen Kesehatan, dan Departemen Kependudukan dan Lingkungan Hidup.

Dalam proses lahirnya suatu

\footnotetext{
${ }^{10}$ Michael Howlett and M. Ramesh : 1995, Studying Public Policy, Toronto, New York Oxford, Oxford University Press, Hlm. 52
}

kebijakan publik maka tidak akan terlepas dari proses perumusan kebijakan oleh pihak eksekutif atau birokrat, setelah masalah publik di tanggapi oleh pihak eksekutif dengan dibuatnya agenda mengenai hal itu selanjutnya akan dirumuskan ketentuan atau materi kebijakan tersebut. Materi yang merupakan muatan dari kebijakan publik itu dan ruang lingkup berlakunya kelak akan menentukan bentuk hukum dari kebijakan tersebut. Apakah suatu kebijakan lokal atau daerah, ataukah kebijakan nasional, regional ataukan internasional.

Selain terkait dengan pihak eksekutif, maka selanjutnya juga akan melibatkan peran legislative. Menurut Jaya, Sigler Benjamin R. Beede bahwa "Legislative Committees. A participant recently described the policy making process in Congress in the way." kemudian dikatakannya bahwa " Since this description was written from the congressional perspective, executive initiatives received less emphasis than they merit is the often the executive brach that starts formulating a new policy or changing an exisiting policy." ${ }^{11}$ Jadi menurutnya eksekutif juga turut berperan dalam hal proses pembuatan kebijakan publik. Dimana setelah dirumuskan kebijakan publik maka dilakukan penentuan bentuk hukumnya dengan dilakukannya pengesahan terhadap kebijakan tersebut.

\footnotetext{
${ }^{11}$ Jay A. Sigler and Benjamin R. beede, 1977, The legal Sources Of Public Policy, Toronto, Uniteed States, By D.C Health and Company, Hlm. 13
} 


\section{Pengaruh Kebijakan Negara Terhadap Kelangsungan ketersedian Air Bersih sebagai Implementasi Keadilan Sosial Ekonomi.}

Ketersediaan air bersih adalah suatu hal yang sangat diperlukan oleh manusia, karena secara alamiah manusia tidak akan dapat terlepas dari air dalam menjalani kehidupannya. Ketersediaan air bersih yang tidak terpenuhi berarti menunjukan adanya krisis air bersih dalam fenomena kehidupan manusia. Krisis air adalah dimensi kerusakan ekologis bumi yang paling menyebar, paling sulit dan paling tidak terkendali. Permasalah ijin ini bukan hanya sekedar berkaitan dengan pertumbuhan penduduk yang semakin tinggi, tetapi juga dikarenakan adanya tingkah laku manusia dalam penggunaan air yang tidak benar. Seringkali aktivitas manusia merusak ekosistem lingkungan yang pada akhirnya juga menyebabkan rusaknya persedian air yang ada di muka bumi ini. Kapasitas tanah untuk dapat menyimpan air resapan ternyata mulai berkurang kemampuannya akibat banyaknya kesalahan manusia dalam menggunakan alam, tanah dan kesalahan dalam perencanaan suatu pembangunan tertentu. Misalnya pula pembabatan hutan yang semakin tinggi jumlahnya, kegiatan pertambangan yang tidak terkendalikan dan berakibatnya merusak kemampuan daya serap tanah hutan tersebut untuk menyimpan air. Akibat industrialisasi dan akibat tingginya kuantitas penggunaan Bahan Bakar minyak, yang turat menyebabkan pemanasan global yang sangat berakibat buruk pada ketersediaan air permukaan buini ini, banyak terjadi kekeringan panjang, karena siklus musim yang mulai tidak stabil lagi, dana berbagai macam persoalan lain yang berhubungan dengan penyebab terjadinya krisis air bersih bagi manusia di dunia ini.

Meluasnya konflik air di Indonesia ini menyebabkan pemerintah Indonesia terlibat dalam penanggulangan persoalan ini, dengan ikut serta menjadi bagian dari berbagai kebijakan internasional yang berkaitan dengan persoalan penanggulangan krisis air. Indonesia memang sebagai negara yang dulunya terkenal sebagai negara yang kaya akan sumber daya alam, kaya akan sumber daya hutan, kaya akan sumber daya air. Namun akhir-akhir ini bahkan diprediksaikan 10 atau 20 tahaun mendatang negara kita akan mengalami krisis air, sekarang saja di beberapa wilayah di Indonesia ini sudah sering terjadi kelangkaan air baku, sehingga menyebabkan sering terjadi penurunan tingkat produksi air bersih oleh beberapa perusahan air minum di negeri ini.

Kelangkaan air di negeri ini seyogyanya segera diselesaikan dengan dicari akar permasalahannya, juga model penggeloalaan air yang selama ini banyak yang kurang benar maka segera dibenahi dan diperbaiki. Jangan sampai persoalan kelangkaan air menjadikan ironisnya istilah air sumber kehidupan sementara disisi lain pemerintah semakin giat meningkatkan sumber dana dari sektor pertambangan dan juga perkebunan yang seringkali tanpa memperhatikan persoalan air, sementara pada saat yang sanra sumber daya air kian menyusut. 
Persoalan krisis air bersih ini jika dikaitkan dengan kebijakan menanganinya malca apabila terjadi salah urus dalam pengelolaan sumber daya air di negeri ini akan semakin menyebabkan bertambahnya krisis air bersih. Praktek pengurusan persoalan air ini bermuara di kebijakan pemerintah mengenai pengelolaan sumber daya air. Apabila kebijakan ini dibentuk dengan baik dari melihat permasalahan secara benar maka akan menghasilkan rumusan kebijakan yang baik dan pada akhirnya akan mencapai tujuan untuk kepentingan publik atau masyarakat. Menurut M. Irfan Islamy bahwa kesalahan dalam melihat dan mengidentifikasikan permasalahan publik, maka akan berakibat salahnya dalam perumusan masalah dan pada akhirnya akan berdampak buruk pada fase-fase selanjutnya. ${ }^{12}$

Kebijakan privatisasi air yang digariskan dalam kebijakan mengenai sumber daya air yakni yang tertuang dalam UU Nomor 7 Tahun 2004 tentang SDA, menyebakan sekarang ini semakin banyaknya di buat kebijakan daerah dalam bentuk PerDa yang memberikan peluang besar untuk swastanisasi di bidang pengeloaan sumber daya air. Keyakinan Pemerintah terhadap privatisasi di bidang SDA ini membuat pemerintah seolah reaktif dengan segera melahirkan kebijakan yang memberikan peluang besar kepada investor baik asing maupun domestik dalam usaha berkenaan dengan sumber daya air di

${ }^{12}$ M.Irfan Islamy: 200". Prins if-Prms if Perumusan Kebijakan Publik.Jakarta, PT.Bumi Aksaia, Hlm.81
Indonesia. Bahkan sampai menjual aset negara kepada swasta asing, hal ini dikhawatirkan akan berdampak buruk pada tingkat perekonomiam bagi masyarakat indonesia terutama bagi masyarakat miskin, menyengsarakan rakyat. Sekarang ini nampaknya bangsa kita sedang mengalami proses dehumanisasi yang sering mengakibatkan kebijakan-kebijakan negara yang tidak pro rakyat.

Apalagi sekarang ini kebijakan publik yang dibuat pemerintah yang berkenaan dengan sumber daya air, dengan menumbuhkan program swastanisasi atau privatisasi di bidang pengeloaan sumber daya air. Kalau ditelaah sepintas memang nampaknya bertujuan untuk meningkatkan ketersediaan air bersih bagi masyarakat. Karena dengan kehadiran investasi swasta di bidang air termasuk dalam usaha produksi air bersih dan pengeloaan sumber daya air lainnya, yang diharapkan akan dapat meningkatkan kinerja perusahaan air untuk meningkatkan kuantitas produksinya yang dapat dinilai sebagai usaha meningkatkan ketersediaan air bersih. Tetapi jika ditelaah lebih mendalam lagi, ternyata kebijakan privatisasi di bidang sumber daya air di Indonesia ini akan sangat berpengaruh kepada akses masyarakat miskin terhadap ketersedian air bersih bagi kehidupan mereka. Bagaimana tidak, dengan adanya kebijakan privatisasi tersebut yang telah digariskm dalam UU Nomor 7 Tahun 2004 tentang SDA dan PP Nomor 16 tahun 2005 tentang Sistem penyediaan Air Minum. Hal ini merupakan pelanggaran akan hakikat tanggurg jawab pemerintah 
terhadap warganegaranya. Karena sebenarnya dalam UU Nomor 7 Tahun 2004 dan PP Nomor 16 tahun 2005 mengamatkan bahwa ketersediaan air bersih bagi warganegara adalah tanggungjawab pemerintah baik pemerintah pusat maupun daerah. Kalau pemerintah mau lepas tangan akan tanggungjawabnya ini dengan menyerahkan kepada swasta, maka akan banyak kekhawatiran kita bahwa hal tersebut akan berpengaruh pada pembiayaan yang tinggi yang harus dibebankan kepada rakyat pengguna air bersih tersebut. Bahkan tidak mustahil pada akhrinya rakyat akan terkesampingkan dalam kegiatan pengeloaan sumber daya air karena semua sumber daya air di negeri ini dikmuasai swasta. Dan akbirnya rakyat negeri ini akan membayar mahal untuk menggunakan sumber daya air yang akan merreka gunakan, meskipun pada hakekatnya sumber daya air di negeri ini adalah hak mereka sebagai warganegara. Bila hal ini terjadi maka akan berpengaruh buruk pada usaha pemerintah untuk menjaga kelangsungan ketersediaan air bersih bagi masyarakat, sebagaimana yang digariskan dalam kesepakatan MDGs agar pemerintah meningkatkan akses masyarakat miskin terhadap air bersih.

Tanpa melakukan langkahlangkah yang konkret serius dalam bentuk intervensi program dan pembiayaan lansung dari sumber anggaran publik dan penguatan peran sektor publik, krisis air bersih di Indonesia ini akan bertambah parah di waktu mendatang dan sulitnya negara kita mewujudkan target MDGs.

Laporan bank Dunia (Wold
Bank) dalam Indonesia Public Expenditure review 2007 mengidentifikasikan bahwa sebenarnya pemerintah Indonesia saat ini memiliki ruang fiskal ( fiskal space ) yang cukup besar untuk mengalokasikan dana untuk investasi membangun infrastruktur dasar (listrik, air bersih, jalan dan telekomunikasi. ${ }^{13}$

Kebijakan negara dibidang air ini, kalau kita cermati dengan melihat kepada model-model kebijakan publik maka akan kita dapat lihat bahwa dalam pembentukan Kebijakan ini ternyata dapat dinilai telah menggunakan Model Institusional (Institutional Activity), yakni model pembuatan Kebijakan Publik yang terfokus pada adanya struktur organisasi pemerintah. Kebijakan Publik ini dirumuskan dan dilaksanakan pada lembaia-lembaga pemerintahan. Dimana kebijakan dalam model ini, dibuat oleh pemerintah dengan kurang melibatkan partisipasi masyarakat. Dilihat pada kebijakan publik berkenaan dengan air bersih ini, ternyata dapat dilihat dalam prosesnya kurang melibatkan masyarakat sehingga dirasakan kebijakan ini tidak pro rakyat.

Kemudian ketika kita mencoba menganalisa berkenaan dengan privatisasi dalam hal pengelolaan SD Air di Indonesia, maka kita akan dapat cermati bahwa penguasaan SD Air oleh privat (swasta) cenderung mengikuti proses mekanisme pasar kapilatistik dan liberalism yang seringkali bermuara pada beban konsumen

13 IeSR, KRUHA dan INFID, Mengaiasl Krisis Air Bersih Memeriukan Komitmen dan Peran Aktlf Negara, Rubrik Surat Pembaca dalam Majalab Bulanan Air Minum, Edisi 138, Maret 2007. 
yang besar. ${ }^{14} \mathrm{Hal}$ ini sangat riskan jika kita relevansikan dengan ketentuan dalam konstitusi kita yang mengariskan adanya hak menguasai Negara untuk kemakmuran rakyat, yang menggariskan pula bahwa cabang produksi yang penting bagi rakyat yang menguasai hajat hidup orang banyak Negara harus mengelolanya dengan sebaikbaiknya untuk tujuaan kemakmuran rakyat. Kemakmuran rakyat merupakan implementasi dari nilai keadilan social yang ingin dituju oleh konstitusi kita. UUD 1945 telah lama mengamanatkan system ekonomi yang bertujuan untuk kesejahteraan rakyat atau kemakmuran sosial, yang tentunya tujuan mulia ini penting diperhatikan oleh Negara dalam setiap perumusan kebijakan Negara dalam berbagai peraturan hukum yang dirumuskan sebagai bagian dari politik hukum yang baik. Memang kita juga sadari tentu ada berbagai kesulitan dalam mengimplementasikan kemakmuran rakyat sebagai tujuan setiap kebijakan Negara tertuama yang terkait dengan bidang ekonomi, karena harus berhadapan dengan perkembangan dunia secara global yang mengarahkan dunia pada fenomena faham kapilatis dan liberalisme yang juga menumbuhkan era pasar bebas dan persaingan bebas.Namun meskipun demikian kondisinya tentunya Negara pantas untuk lebih konsisten dengan apa yang tertuang dalam konstitusi Negara.Dalam artian kebijakan Negara harus dikembalikan pada tujuan konsitusi.

Kalau kita telaah konstitusi kita, adanya demokrasi ekonomi yang tertuang dalam ketentuan pasal

${ }^{14}$ Suteki, Op.Cit, hlm. 10
33 UUD 1945 sepantasnya sebagai acuan setiaap bagiu perumus kebijakan Negara terutama yang berkenaan dengan bidang ekonomi.Karena pada hakekatnya apa yang tetuang dalam pasal 33 tersebut merupakan filosofis ketatanegaraan yang mengupayakan pencapaian tujuan sebesar-besarnya kemakmuran rakyat.Kemakmuran rakyat ini diimplementasikan dalam bentuk pemenuhan hak dan kepentingan publik,sehingga dikatakan bahwa kepentingan dan hak publik termasuk untuk aksesnya terhadap berbagai kebutuhannya di bidang ekonomi, sebagai arus utama yang didahulukan daripada kepentingan pribadi dan golongan.Sehingga tentulah peran pemerintah sebagai penguasa Negara untuk dapat menentukan arah kebijakannyaa dalam tujuan tersebut. Apalagi jika kita hubungkan dengan cabangcabang produksi yang penting yang menguasai hajat hidup orang banyak dikuasai Negara maka seyogyanya juga untuk dipergunakan sebesarbesarnya bagi kemakmuran rakyat, karena itulah perlu peran Negara dalam hal mengatur dan menentukan untuk terselengaranya pengelolaan sumber daya alam termasuk SD Air untuk tujuan kemakmuran rakyat karena ayat (3) UUD 1945 mengamanatkan demikian.

Kajian tentang demokrasi ekonomi yang tertuang dalam pasal 33 UUD 1945, bahwa demokrasi ekonomi itu pada prinsifnya memiliki ciri positif, yaitu :

1. Perekonomian disusun atas usaha bersama berdasarkan asas kekeluargaan

2. Cabang-cabang produksi yang penting bagi Negara dan 
menguasai hajat hidup orang banyak dikuasai oleh Negara

3. Bumi, air dan kekayaan alam yang terkandung didalamnya dikuasai oleh Negara dan dipergunakan sebesar-besarnya untuk kemakmuran rakyat.

4. Sumber-sumber kekayaan dan keuangan Negara dipergunakan dengan permufakatan lembagalembaga perwakilan rakyat, serta pengawasan terhadap kebijaksanaannya ada pada lembaga perwakilan rakyat pula.

5. Warga negara memiliki kebebasaan dalam memilih pekerjaan yang dikehendaki serta mempunyai hak akan pekerjaan dan penghidupan yang layak.

6. Hak perorangan di akui dan pemanfaaatannya tidak boleh bertentangan dengan kepentingan masyarakat.

7. Potensi,inisiatif dan daya kreasi setiap warga Negara diperkembangkaan sepenuhnya dalam batas-batas yang tidak merugikan kepentingan umun.

8. Fakir miskin dan anak terlantar dipelihara oleh Negara. ${ }^{15}$

Garis

kebijakan

ketatanegaraan kita secara umum yang tertuang dalam konstitusi kita sudah mengarahkan pada tujuan kesejahteraan rakyat sebagai suatu nilai keadilan sosial yang tinggi dalam tataran nilai falsafah bangsa kita. Dan penghargaan akan hak asazi manusia dalam bidang ekonomi juga sangat jelas terlihat, bagaiamna hak perorangaa diakui hak memiliki kehidupasn yang layak juga diakui sepanjang pemenuhan kepentingan pribadi tetap dalam koridor norma sosial yang dengan tidak merugikan kepentingan orang

\footnotetext{
${ }^{15}$ Soementoro, Hukum Ekonomi, Jakarta, UI Press, hlm. 23
}

banyak.kemudian sumber daya alam juga diserahkan pada Negara sebagai penguasanya dengan tujuan kea rah pemenfaatan dan pengelolaan yang baik guna kesejahteraan sosial yakni kemakmuran rakyat.cabang-cabang produksi yang penting dan menguasai hajat hidup orang banyak juga diserahkan pada Negara dalam penguasaannya (hak menguasai Negara) sehingga melahirkan pula BUMN dan BUMD. Demikian pula untuk SD Air, banyak dibentuk BUMN atau BUMD yang berusaha dalam pengelolaan SD Air untuk pemenuhan kebutuhan masyarakat dalam hal air bersih dan air minum. Namun ketika dihadapkan dengan arah kebijakan perekonomian kita yang mengarah kepada privatisasi sungguh hal ini perlu untuk terus dicermati mengingat system privatisasi adalah anak kandung yang lahir dari faham kapitalisme dan liberalisme ekonomi.

Sistem demokrasi ekonomi yang dipilih oleh para pendiri bangsa ini yang tercantum dalam konstitusi Negara, menunjukkan hakekat keaadilan sosial sebagai suatu tujuan dari implementasinya dengan konsep pengelolaan Sumber daya alam termasuk sumber daya air dengan peruntukannya kepada kemakmuran rakyat. Sementara system privatisasi yang masuk dalam kebijakan Negara berkenaan dengan pengelolaaan SD Air yang terlihat pada beberapa pasal dalam UU SD Air (UU Nomor 7 tahun 2004) dan peraturan pelaksananya. Menjadi suatu yang perlu diwaspadai berkenaan dampak negative yang mungkin terjadi dari kebijakan tersebut. Apalagi berkenaan dengan kelangsungan dan penguasaan saham pada beberapa 
perusahaan air minum atau PAM yang apabila banyak dikuasai swasta apakah dapat berdampak positif pada akses masyarakat akan air bersih atau air minum, dikhawatirkan distribusi air bersih tidak dapat mencapai masyarakat miskin dan marginal karena keterbatasan ekonomi atau pendapatan mereka sehingga sulit menjaungkau pelayanan air bersih yang dikelola swasta tersaebut. Sebab sudah menjadi suatu hal yang lumrah apabila suatu perusahaan swasta dibangun dan dijalankan dengan obsesi pada profit. Dalam mengimplementasikan profit yang diharapkan swasta baik swasta dalam negeri maupun asing adakalanya kepentingan dan kesejahteraan masyarakat terkesampingkan karenanya. Demikian juga dalam hal tersedianya air bersiah atau air minum untuk masyarakat, apakah dapat dijamin bahwa akses masyarakat miskin terhadap air bersih akan terpenuhi. Dan pada akhirnya akan dipertanyakan banyak pihak tentang fungsi dan tugas Negara untuk menjamin hal tersebut. Jika dicermati lebih jauh lagi, ternyata kebijakan privatisasi di bidang sumber daya air di Indonesia ini akan sangat berpengaruh kepada akses masyarakat miskin terhadap ketersedian air bersih bagi kehidupan rnereka. Bagaimana tidak, dengan adanya kebijakan privatisasi tersebut yang telah tersirat dalam UU Nomor 7 Tahun 2004 tentang SDA dan PP Nomor 16 tahun 2005 tentang Sistem penyediaan Air Minum. Hal ini dapat dikategorekan sebagai pelanggaran akan hakikat tanggung jawab pemerintah tarhadap warganegaranya. Karena sebenarnya dalam UU Nomor 7 Tahun 2004 dan PP Nomor 16 tahun 2005 mengamanatkan bahwa ketersediaan air bersih bagi warganegara adalah tanggungjawab pemerintah baik pemerintah pusat maupun daerah. Kalau pemerintah mau lepas tangan akan tanggungjawabnya ini dengan men yerahkan kepada swasta, maka akan banyak kekhawatiran kita bahwa hal tersebut akan berpengaruh pada pembiayaan yang tinggi yang harus dibebankan kepada rakyat pengguna air bersih tersebut. Bahkan tidak mustahil pada akhrinya rakyat akan terkesampingkiin dalam kegiatan pengeloaan sumber daya air karena semua sumber daya air di negeri ini dikuasai swasta. Dan akhirnya rakyat negeri ini akan membayar mahal untuk menggunakan sumber daya air yang akan mereka gunakan, meskipun pada hakekatnya sumber daya air di negeri ini adalah hak mereka sebagai warganegara.

Akses pemenuhan kebutuhan akan air bersih atau air minum merupakan suatu hal penting dalam kehidupan masyarakat, karena ini menyangkut hakekat kehidupan manusia itu sendiri sebagai hak asazi untuk hidup dan mempertahankan hidup. Dalam konsep tujuan Negara untuk mensejahterakan rakyatnya dan melindungi hak asazi manusia, maka persoalaan ketersedian dan akses masyarakat akan air bersiah atau air minum merupakan suatu yang perlu diperhatikan. Dalam tujuan Negara untuk kesejahteraan rakyatnya, maka memperhatikan nilai keadilan sosial di bidang ekonomi dan pengelolaan SD Air sesuai konsep Negara hukum dengan demokrasi 
ekonominya mau tidak mau harus mengutamakan kepentingan rakyat untuk kesejahteraan dan kemakmuran bersama. Sehingga sepatutnya perumusan kebijakan hukum dalam setiap kebijakan Negara yang tertuang dalam berbagai peraturan hukum hendaknya mencerminkan hal itu.

Peraturan hukum yang pro rakyat di segala bidang pembangunana hukum termasuk di bidang ekonomi sepatutnya jangan terlepas dari konsep dan tujuan utama untuk kemakmuran rakyat. Sehingga kompleksitas kenyataan dalam kehidupan masyarakat termasuk kebutuhan sosial yang utama, perlu dimasukkan dalam pemahaman dan analisa dalam setiap perumusan untuk pembentukan maupun penerapan aturan hukum. Menurut doktrin ekonomi politik harus memasukkan tafsiran terhadap kebaikan public yang berdasar pada konsepsi keadilan, sehingga memandu refleksi-refleksi rakyat untuk mempertanyakan tentang kebijakan ekonomi dan sosial, yang akan mengambil perspektif konvensi konstitusional dalam legislative yang mengarahkan pada prinsifprinsif keadilan tersebut. ${ }^{16}$

\section{KESIMPULAN}

1. Dalam kaitannya dengan kebutuhan masyarakat akan air bersih, pemerintah sudah membuat berbagai kebijakan yang sifatnya sebagai sebuah kebijakan publik, karena tujuannya untuk kepentingan

16 John Rawls, A Theory Of Justice, (terjemahan oleh Uzair Fauzan dan Heru Prasetyo) , Yogyakarta, Pustaka Pelajar,2011, hln.334 masyarakat atau kepentingan umum. Salah satu kebijakan Negara dalam pengelolaan sumber daya air adalah Kebijakan privatisasi yang digariskan dalam kebijakan mengenai sumber daya air yakni yang tertuang dalam beberapa pasal UU Nomor 7 Tahun 2004 tentang SDA, yang melahirkan kebijakan kebijakan daerah dalam bentuk Perda yang memberikan peluang besar untuk swastanisasi di bidang pengeloaan sumber daya air.

2. Kebijakan tentang privatisasi dalam pengelolaan SD Air dikhawatirkan berdampak negative pada akses masyarakat miskin akan ketersediaan air bersih untuk kehidupannya, sehingga pemenuhan akan tujuan hak menguasai Negara untuk kemakmuran rakyat menjadi sangat rendah, pencapaian kemakmuran rakyat sebagai implementasi keadilan sosial dalam bidang ekonomi sulit terpenuhi.

\section{SARAN}

Dalam menyikapi kebijakan negara tentang privatisasi sumber daya air di negeri ini, seharusnya pemerintah atau perumus kebijakan ekonomi di negeri ini harus berhatihati dalam melakukan program privatisasi tersebut, karena hal ini menyangkut air yang merupakan sumber kehidupan bagi manusia. Apabila program privatisasi itu berdampak buruk bagi kelangsungan ketersedian air bersih bagi masyarakat, maka seyogyanya Negara atau perumus kebijakan Negara tentang sumber daya air dapat mengambil langkah konkret 
untuk meluruskan kembali tujuan demokrasi ekonomi sesuai yang digariskan konstitusi untuk pencapaian kemakmuran rakyat sebagai implementasi dari konsep keadilan sosial di bidang ekonomi, dan sebagai perwujudan tanggung jawab pemerintah terhadap pemenuhan hak warga Negara.

\section{Daftar Pustaka}

Dunn, William N: 2003, Pengantar Analisis Kebijakan Publik, Yogyakarta, Gajahmada University

Dye, Thomas R, Understanding Public Policy, Englewood Cliffs, N.J, 7832, Prentice Hall, Inc., 3rdeed., 1978

Howlett, Michael and M. Ramesh : 1995, Studying Public Policy, Toronto, New York Oxford, Oxford University Press

Islamy, M. Irfan : 2007, PrinsifPrinsif Perumusan Kebijakan Publik, Jakarta, PT.Bumi Aksara

IeSR, KRUHA dan INFID, Mengatasi Krisis Air Bersih Memerlukan Komitmen dan Per an Aktif Negara, Rubrik Surat Pembaca dalam Majalah Bulanan Air Minum, Edisi 138 Maret 2007.

Lubis, M. Solly, 2007, Kebijakan Publik, Bandung : CV. Mandar Maju

Laporan Utama " Air Bersih Harus Naik Kelas jadi Air Minum ", Majalah Bulanan Air minum, Edisi 131 Buian Agustus Tahun 2006

Laporan Khusus Majalah Air Minum "Menyiasati Kelangkaan Air Semoga Tidak Hanya Sekedar Wacana
",Majalah Bulanan Air Minum Edisi April 2007

Rawls, John. : 1995, A Theory of Justice, Cambridge, Massachausetts.

Sigler, Jay A. and Benjamin R. beede $_{\mathrm{r}}$ 1977, The legal Sources Of Public Policy, Toronto, United States, By D.C Health and Company

Suteki: 2010, Rekontruksi Politik hukum Hak Atas Air Pro Rakyat, Semarang, Surya Pena Gemilang. 